\title{
HUBUNGAN KELEKATAN PADA IBU, AYAH, DAN TEMAN SEBAYA DENGAN KECENDERUNGAN ANAK MENJADI PELAKU DAN KORBAN BULLYING
}

\author{
Fasli Arif ${ }^{\text {, }}$ \\ Sri Wahyuni ${ }^{2}$ \\ Fakultas Psikologi \\ Universitas Islam Negeri Sultan Syarif Kasim Riau \\ J1. Subrantas KM. 15, Rimba Panjang, Tambang, Kota Pekanbaru \\ Riau 28293, Indonesia \\ 1e-mail:fasli.arif@yahoo.co.id \\ ${ }^{2}$ e-mail: sri.wahyuni@uin-suska.ac.id
}

\begin{abstract}
Bullying is a behavior of misusing physical force by stronger individuals or groups towards their weaker counterparts, which is intended to hurt and is repeatedly done. The aim of the current study is to investigate the tendency of children to become bullies and victims of bullying in terms of attachment to the mother, father, and peers. Subjects in this study were 250 students with complete parents. This study found that there exists a negative relationship between attachment to mother and father and children's tendency to be bullies. It was also found that only attachment to father that were negatively associated with children's tendency to be victims of bullying. This study also found that peer attachment does not have a significant relationship with children's tendency to be both bullies and victims of bullying. Further, both boys and girls are at risk of becoming victims of bullying.
\end{abstract}

Keywords: attachment; bullies; victim of bullying; adolescence

\begin{abstract}
Abstrak - Bullying adalah perilaku yang menyalahgunakan kekuatan fisik, dilakukan oleh individu atau kelompok yang lebih kuat terhadap individu atau kelompok yang lebih lemah dengan tujuan untuk menyakiti, dan dilakukan secara berulang. Penelitian ini bertujuan untuk melihat kecenderungan anak menjadi pelaku dan korban bullying ditinjau dari kelekatan pada ibu, ayah, dan teman sebaya. Subjek penelitian ialah 250 siswa yang memiliki orangtua yang lengkap. Hasil penelitian menunjukkan bahwa terdapat hubungan yang negatif antara kelekatan dengan ibu dan ayah dengan kecenderungan anak menjadi pelaku bullying, namun hanya kelekatan dengan ayah yang berasosiasi negatif dengan kecenderungan anak menjadi korban bullying. Kelekatan dengan teman sebaya diketahui tidak berasosiasi dengan kecenderungan anak menjadi pelaku dan korban bullying. Anak laki-laki dan perempuan sama-sama berisiko menjadi korban bullying.
\end{abstract}

Kata Kunci: kelekatan; pelaku bullying; korban bullying; remaja 


\section{PENDAHULUAN}

Bullying adalah bentuk perilaku agresif yang dilakukan oleh individu atau kelompok yang lebih kuat terhadap individu atau kelompok yang lebih lemah, bertujuan untuk menyakiti dan dilakukan secara berulang-ulang (Eisenberg, 2006a; Lines, 2008; Olweus, 1997). Perilaku bullying dapat dilakukan secara fisik, verbal, atau psikologis dan dilakukan secara berulang-ulang serta menimbulkan dampak negatif bagi korbannya (Wahyuni \& Asra, 2014).

Perilaku bullying dapat diamati pada pelaku maupun korban, karena masing-masing pihak ini memiliki karakteristik tersendiri (Olweus, 1997). Karakteristik pelaku bullying meliputi pelaku memiliki fisik yang lebih kuat dibandingkan siswa lainnya, kurang mampu memahami dan merasakan apa yang dirasakan oleh orang lain, memiliki sikap positif terhadap kekerasan, agresif terhadap teman sebaya dan orang dewasa, akrab dengan sesama pelaku bullying, kurang mampu mengontrol diri dan impulsif, cenderung mendominasi, tidak mau mentaati norma sosial, sering memaksa korban, serta memiliki perilaku kurang baik di sekolah dan sering dikeluarkan dari sekolah. Selain itu, mereka juga memiliki kelompok, berasal dari keluarga yang mengabaikan, keras, dan otoriter, serta ada riwayat perilaku bullying.

Karakteristik dari korban (victimization) adalah cenderung bersikap pasif dan tunduk terhadap orang yang dianggap mengancam, merasa tidak berharga, tidak akan membalas jika mereka dihina, dan selalu mengalah dengan situasi yang terjadi pada dirinya (Olweus, 1997). Anak yang berisiko menjadi korban bullying ialah anak yang menghindar dari perilaku agresif, menarik diri dari interaksi sosial, pendiam, pencemas, serta tidak mampu membela dirinya (Eisenberg, 2006b).

Perilaku bullying sudah menjadi perhatian di berbagai negara. Nansel dkk. (2001) sebelumnya menemukan bahwa 29.9\% siswa kelas 6-10 di Amerika terlibat perilaku bullying, yaitu 13\% sebagai pelaku, $10.6 \%$ sebagai korban, dan $6.3 \%$ menjadi pelaku sekaligus korban. Selanjutnya Kowalski dan Limber (2013) yang melakukan penelitian pada 903 siswa kelas 6-12 pada dua sekolah di Pennsylvania juga menemukan bahwa sebanyak 132 siswa (14.6\%) pernah setidaknya satu kali menjadi korban, 156 orang (17.3\%) menjadi pelaku, dan 173 orang (19.2\%) menjadi pelaku sekaligus korban bullying dalam 2 bulan sebelum penelitian dilakukan. Selanjutnya, penelitian tersebut juga menemukan bahwa 76 orang (8.4\%) menjadi korban, 74 orang $(8.2 \%)$ menjadi pelaku, dan 33 orang (3.7\%) menjadi pelaku sekaligus korban dengan frekuensi dua sampai tiga kali atau lebih dalam 2 bulan terakhir.

Siswa laki-laki maupun perempuan memiliki risiko terlibat perilaku bullying, baik sebagai pelaku, korban, maupun keduanya (Wolke, Woods, Stanford, \& Schulz, 2001). Namun demikian, 
siswa laki-laki ditemukan lebih tinggi kecenderungan keterlibatan dalam perilaku bullying, baik sebagai pelaku, korban, maupun sebagi pelaku atau korban sekaligus (Wolke dkk., 2001). Hasil penelitian Khezri, Ghavam, Mofidi, dan Delavar (2013) menemukan bahwa 85\% siswa laki-laki dan $72 \%$ siswa perempuan pernah melakukan bullying, yang berada pada kategori ringan dan sedang. Selanjutnya, sekitar $87 \%$ siswa laki-laki dan $73 \%$ siswa perempuan pernah menjadi korban bullying. Secara keseluruhan, $92 \%$ siswa laki-laki dan $84 \%$ siswa perempuan teridentifikasi sebagai pelaku atau korban bullying.

Perilaku bullying terjadi pada semua tingkatan pendidikan. Beberapa kasus bullying banyak terjadi di Sekolah Dasar (SD) dan Sekolah Menengah Pertama (SMP), contohnya kasus di SD Bukit Tinggi (Sudiaman, 2014). Pada kasus ini salah seorang siswi dipukuli temannya, kejadian bermula dari saling mengejek, korban pada awalnya memulai pertengkaran dengan pelaku, korban menghina atau mengejek temannya (pelaku), yang kemudian menyulut emosi pelaku, dan pelaku akhirnya memukul korban dan mengajak teman-teman yang lain juga mengeroyok korban. Kasus lainnya adalah seorang siswi SD mendapatkan tindakan bully dari temannya di sekolah yang menyebabkan saluran kencingnya bernanah (diketahui setelah divisum di Rumah Sakit) mengakibatkan siswi tersebut tidak ingin masuk sekolah dan mengalami trauma (Azzura, 2015). Kasus bullying juga ditemukan di Pekanbaru, terdapat beberapa kasus bullying yang terjadi di lingkungan sekolah, baik di SD, SMP, maupun SMU (Wahyuni \& Nazifah, 2012).

Perilaku bullying memiliki dampak terhadap korban, tidak hanya sekedar luka fisik, namun juga psikologis. Dampak psikologis tersebut antara lain meningkatkan gejala-gejala emosional, misalnya merasa tidak bahagia, tertekan, dan sangat sedih (Malti, Perren, \& Buchmann, 2010), depresi dimana semakin sering terkena bullying maka semakin tinggi tingkat depresinya (Uba, Yaacob, \& Juhari, 2009), rendahnya harga diri (Uba, Yaacob, Juhari, \& Talib, 2010), dan meningkatkan stres (Konishi \& Hymel, 2009). Selain itu, pengalaman bullying di sekolah juga memiliki dampak terhadap performa siswa di sekolah, seperti yang ditemukan oleh Totura dkk. (2009), bahwa baik pelaku maupun korban bullying memiliki performa akademik yang rendah.

Banyak alasan yang menjadikan seseorang menjadi pelaku bullying, namun alasan yang paling jelas bahwa pelaku bullying merasakan suatu kepuasan apabila ia memiliki kekuasaan di kalangan teman sebayanya (Sejiwa, 2008). Dengan melakukan tindakan bullying, ia akan mendapatkan label bahwa betapa "besar" dirinya dan betapa "kecil”-nya sang korban. Hal itu terjadi karena teman yang satu kelompok dengan pelaku selalu memberikan sanjungan dan akhirnya pelaku terdorong untuk sering melakukan bullying (Sejiwa, 2008). 
Pelaku bullying umumnya memiliki sifat yang temperamental terhadap orang lain sebagai pelampiasan kekesalan dan kekecewaannya. Pelaku bullying kemungkinan besar juga sekedar mengulangi apa yang pernah dilihat dan apa yang mereka alami sendiri. Anak yang dahulunya mendapatkan perlakuan yang kasar dari orang-orang yang mem-bully atau anak yang menjadi korban bullying kemungkinan menyimpan dendam dan kejengkelan yang akan mereka lampiaskan suatu saat kepada orang lain (Sejiwa, 2008).

Glew, Fan, Katon, Rivara, dan Kernic (2005) menemukan bahwa siswa yang menjadi korban bullying memiliki prestasi akademik yang rendah, merasa tidak aman di sekolah, merasa tidak memiliki sekolahnya, dan merasa sedih, dibandingkan siswa yang tidak menjadi korban bullying. Demikian juga halnya dengan siswa yang menjadi pelaku bullying, mereka juga merasa tidak aman dan sedih, yang kemudian mengganggu temannya sehingga terjadi pertengkaran. Andreou (2001) sebelumnya juga menemukan bahwa baik siswa yang menjadi pelaku maupun korban bullying sama-sama memiliki penerimaan sosial dan kemampuan memecahkan masalah yang rendah. Selain hanya menjadi pelaku atau korban bullying, anak dapat sekaligus menjadi keduanya yaitu menjadi pelaku dan korban bullying.

Penelitian sebelumnya menemukan bahwa ada dua faktor yang memengaruhi anak berperilaku bullying, yaitu faktor internal dan eksternal. Faktor internal antara lainkemampuan berempati, kemampuan mengendalikan diri, sikap terhadap perilaku kekerasan, dan sikap terhadap permusuhan. Sedangkan faktor eksternal antara lain pola asuh orangtua, kelekatan antara anak dan orangtua, iklim sekolah, dan lingkungan (Wahyuni \& Asra, 2014).

Pada penelitian ini, peneliti fokus pada salah satu faktor eksternal yang memengaruhi kecenderungan menjadi pelaku dan korban bullying, yaitu kelekatan dengan ibu, ayah, dan teman sebaya. Orangtua, khususnya ibu, berperan sebagai figur sentral dalam proses perkembangan anak (Wahyuni \& Asra, 2014). Malekpour (2007) menyatakan bahwa hubungan antara orangtua dan anak yang lekat dengan aman (secure attachment) pada awal kehidupan anak berpengaruh terhadap kematangan otak anak. Anak yang memperoleh kelekatan yang aman (secure attachment) memiliki pertumbuhan dan kematangan otak yang lebih baik, sedangkan anak yang mengalami kelekatan yang tidak aman (insecure attachment) cenderung mengalami psikopatologi.

Menurut Bowlby (1958), kelekatan adalah kehangatan, keintiman, dan hubungan yang berkelanjutan antara ibu dan bayi, dan hubungan tersebut memunculkan kepuasan dan kebahagiaan. Kualitas kelekatan seorang anak sangat ditentukan oleh bagaimana pengasuhan dilakukan pada anak, yang mana pengasuhan yang penuh dengan rasa kasih sayang dan responsif meningkatkan kelekatan aman dan menurunkan kelekatan tidak aman (O’Connor \& Scott, 2007). Rasa aman 
sendiri diperoleh oleh anak melalui kelekatan (attachment) yang terjalin secara emosional antara anak dengan ibu, ayah, dan teman sebaya (Walden \& Beran, 2010).

Setiap anak membutuhkan dukungan dan perhatian lebih dari orang-orang yang berada di dekatnya, agar dapat membantu menghadapi tugas atau fase-fase perkembangan, dan orang-orang yang dianggap penting dalam perkembangan anak, terutama pada masa anak-anak akhirmenuju remaja adalah orangtua dan teman. Orangtua yang memberikan pola interaksi atau pengasuhan yang positif dapat membuat anaknya menjadi mampu untuk menyesuaikan diri di lingkungan sosial walaupun kondisi lingkungan sulit dan penuh tekanan, sehingga anak menjadi lebih memiliki kompetensi sosial (Leidy, Guerra, \& Toro, 2010). Kualitas interaksi antara anak dan orangtua tergambar dari kualitas kelekatan antara anak dan orangtua (Oates, 2007).

Anak yang ketika masih bayi memperoleh kelekatan yang aman (secure attachment) dengan orangtuanya, ketika memasuki usia kanak-kanak ia menjadi lebih mandiri dan percaya diri, mampu menyesuaikan diri dengan teman-teman sebaya dan guru, mampu berkonsentrasi, rasa ingin tahu yang tinggi dan motivasi di sekolah, serta memiliki kemampuan problem solving yang tinggi (Appleyard \& Berlin, 2007). Anak yang mengalami gangguan kelekatan (insecure attachment) cenderung mengalami masalah dalam perkembangan dan penyesuaiannya, keterampilan sosialnya buruk, misalnya menarik diri atau agresif, keterampilan berkomunikasinya buruk, tidak responsif, mudah terganggu, kurang rasa ingin tahu, dan motivasi berprestasinya kurang (Appleyard \& Berlin, 2007).

Ibu yang memiliki perilaku yang responsif, konsisten, serta memberikan pengasuhan dan perawatan yang sesuai dengan kebutuhan anak dikatakan memiliki sifat keibuan, sehingga dapat membuat anaknya membentuk kualitas kelekatan yang aman (secure attachment) yang dalam hal ini akan membantu anak melewati masa perkembangan yang baik dan optimal, dan sebaliknya ibu yang kurang responsif dan kurang peka terhadap perkembangan anaknya maka dapat membuat anak mengalami gangguan kelekatan (attachment disorder) karena memiliki kualitas kelekatan yang tidak aman (Wahyuni \& Asra, 2014). Demikian juga halnya dengan kualitas kelekatan antara anak dengan ayah. Ayah yang berinteraksi dengan anak secara positif menjadikan anaknya mampu menjalin hubungan sosial positif yang timbal balik dengan teman sebaya (Veríssimo dkk., 2011).

Walden dan Beran (2010) melakukan penelitian mengenai hubungan antara kualitas attachment orangtua dengan kecenderungan perilaku bullying pada anak SD, dan menemukan bahwa kualitas attachment yang rendah memiliki hubungan dengan kecenderungan anak untuk menjadi pelaku dan korban bullying, begitu juga sebaliknya, kualitas attachment yang tinggi dapat 
menghindarkan anak dari menjadi pelaku dan korban bullying. Pei (2011) juga menemukan bahwa anak yang memiliki pengalaman kelekatan yang kurang nyaman (insecure attachment) dan kurangnya kehangatan dengan orangtuanya cenderung melakukan perilaku agresif.

Selain kelekatan yang diciptakan oleh ibu, ayah juga berperan penting dalam pertumbuhan dan perkembangan anak, karena ayah merupakan figur utama dalam rumah tangga yang akan ditiru oleh anak dalam kepemimpinannya. Day dan Lamb (dalam Santrock, 2007a) mengungkapkan bahwa terjadi perubahan yang sangat besar pada peran ayah dalam keluarga di Amerika Serikat. Selama masa penjajahan di Amerika, ayah terutama bertanggung jawab atas pengajaran moral. Adanya revolusi industri, fokus peran ayah berubah untuk menekankan posisinya sebagai pencari nafkah bagi keluarga. Menjelang tahun 1970, minat ayah sebagai orangtua aktif dan penyayang mulai muncul. Mereka tidak hanya bertanggung jawab untuk mendisiplinkan dan mengontrol anakanak yang lebih tua dan mencari nafkah bagi keluarga, ayah juga melibatkan diri secara aktif dalam pengasuhan anak (Santrock, 2007a). Hubungan yang baik antara anak dengan orangtua memengaruhi hubungan anak dengan teman sebayanya di luar rumah. Schneider, Atkinson, dan Tardif (2001) menemukan bahwa anak yang memiliki kelekatan yang bagus dengan orangtuanya memiliki kemampuan menjalin hubungan pertemanan yang bagus, baik dengan teman sebaya maupun dengan orang-orang yang dikenalinya, yang selanjutnya juga terjalin kelekatan yang aman antara anak dengan teman sebayanya.

Anak pada tahapan perkembangan remaja, yang memiliki kelekatan yang aman dengan teman sebaya (peer attachment) akan mampu mengkomunikasikan secara terbuka mengenai emosi negatif yang ia rasakan (Rasyid \& Suminar, 2012). Hal itu dikarenakan kelekatan merupakan suatu hubungan yang erat antara seseorang dengan orang lain yang terbentuk karena adanya jalinan komunikasi yang baik (Armsden \& Greenberg, 2009). Ketika remaja, individu cenderung mencari kedekatan dan kenyamanan dalam bentuk saran atau nasihat kepada teman sebayanya ketika mereka merasa membutuhkannya (Hazan \& Shaver, 1994).

Terciptanya kelekatan yang baik di lingkungan keluarga, khususnya ayah dan ibu serta lingkungan sosialnya (teman sebaya), akan menentukan kualitas kelekatan yang dimiliki oleh seorang anak. Appleyard dan Berlin (2007) mengungkapkan bahwa kualitas kelekatan berpengaruh terhadap perkembangan anak. Anak yang mengalami kelekatan yang aman memiliki kesehatan sosial, emosional, kognitif, dan motivasi yang tinggi. Sebaliknya anak yang mengalami kelekatan yang tidak aman kurang memiliki kesehatan sosial, sosial, kognitif, dan motivasi yang rendah. Menurut Rasyid dan Suminar (2012), kelekatan yang aman dengan teman sebaya diprediksi mampu menurunkan kecenderungan anak menjadi terlibat dengan perilaku bullying, karena kelekatan yang 
aman dengan teman sebaya akan menjadikan anak mampu mengkomunikasikan secara terbuka mengenai emosi negatif yang ia rasakan.

Seperti yang telah dijelaskan di atas, hasil penelitian yang sudah ada umumnya hanya melaporkan adanya hubungan antara kelekatan dengan perilaku bullying yang dilakukan oleh pelaku. Belum ada penelitian yang secara utuh melaporkan hubungan kelekatan anak dengan orangtua maupun teman sebayanya dengan kecenderungan anak menjadi pelaku dan korban bullying. Oleh karena itu, penelitian ini bertujuan untuk mengetahui ada tidaknya hubungan antara kelekatan pada ibu, ayah, dan teman sebaya dengan kecenderungan anak menjadi korban dan pelaku bullying. Hipotesis pada penelitian ini terdiri: (1) Ada hubungan antara kelekatan pada ibu, ayah, dan teman dengan kecenderungan anak menjadi pelaku bullying; dan (2) Ada hubungan antara kelekatan pada ibu, ayah, dan teman sebaya dengan kecenderungan anak menjadi korban bullying.

\section{METODE}

\section{Partisipan}

Partisipan pada penelitian ini berjumlah 250 orang yang berusia dari 10 sampai 15 tahun; terdiri atas 136 orang (54.4\%) siswa SD dan 114 orang (45.6\%) siswa SMP. Dari 250 partisipan ini, diketahui 112 orang $(44.8 \%)$ berjenis kelamin laki-laki dan 138 orang (55.2\%) berjenis kelamin perempuan.

\section{Desain}

Penelitian ini menggunakan metode penelitian kuantitatif dengan jenis penelitian causational. Penelitian ini menghubungkan tiga independent variable dan dua dependent variable. Independent variable pada penelitian ini adalah kelekatan dengan ibu, kelekatan dengan ayah, dan kelekatan dengan teman sebaya. Dependent variable pada penelitian ini adalah kecenderungan anak menjadi pelaku bullying dan kecenderungan anak menjadi korban bullying.

\section{Instrumen}

Alat ukur yang digunakan adalah skala kelekatan dan skala kecenderungan menjadi pelaku dan korban bullying. Skala kelekatan yang digunakan adalah Inventory of Parent and Peer 
Attachment (IPPA) yang disusun oleh Armsden dan Greenberg (2009) berdasarkan aspek kelekatan yaitu kepercayaan (trust), komunikasi (communication), dan keterasingan (alienation). Kemudian skala ini dimodifikasi oleh Wahyuni dan Asra (2014), namun peneliti tetap melakukan uji coba kembali. Analisis uji coba alat ukur menggunakan aplikasi Rasch Model yaitu dengan melihat daya diskriminasi butir yang sesuai (fit) dan tidak sesuai (misfit) dan mengetahui nilai valid dan reliabilitas butir (Sumintono \& Widhiarso, 2014).

Nilai reliabilitas butir skala kelekatan berada pada kategori tinggi dengan nilai Alpha Cronbach sebesar .872 untuk skala kelekatan pada ibu, .849 skala kelekatan pada ayah, dan .832 untuk skala kelekatan pada teman sebaya. Berikut ini adalah sebaran butir untuk masing-masing skala kelekatan kepada ibu, ayah, dan teman sebaya.

Tabel 1.

Sebaran Butir Skala Kelekatan pada Ibu

\begin{tabular}{|c|c|c|c|c|}
\hline No & Aspek & Favorable & Unfavorable & Jumlah \\
\hline 1 & Trust & $3,4,6$ & 2,5 & 5 \\
\hline 2 & Communication & 7,9 & 8 & 3 \\
\hline \multirow[t]{2}{*}{3} & Alienation & $11,15,16$ & 12,14 & 5 \\
\hline & & & Total & 13 \\
\hline
\end{tabular}

Tabel 2.

Sebaran Butir Skala Kelekatan pada Ayah

\begin{tabular}{llllc}
\hline No & Aspek & Favorable & Unfavorable & Jumlah \\
\hline 1 & Trust & $1,6,7,9$ & 5,8 & 6 \\
2 & Communication & $10,13,15,16$ & 11 & 5 \\
3 & Alienation & 17,22 & 18,21 & 4 \\
\hline & & & \multicolumn{3}{c}{ Total } & $\mathbf{1 5}$ \\
\hline
\end{tabular}

Tabel 3.

Sebaran Butir Skala Kelekatan pada Teman Sebaya

\begin{tabular}{llllc}
\hline No & Aspek & Favorable & Unfavorable & Jumlah \\
\hline \multirow{2}{*}{ Trust } & $2,3,4,5,6,7$, & 8 \\
& & 8,9 & \\
2 & Communication & $10,11,12,13$, & 7 \\
3 & Alienation & $14,15,16$ & $17,18,20,21$ & 4 \\
\hline & & Total & $\mathbf{1 9}$ \\
\hline
\end{tabular}

Skala kecenderungan menjadi pelaku dan korban bullying yang digunakan adalah skala bullying yang disusun oleh Wahyuni dan Asra (2014). Peneliti tetap melakukan uji coba alat ukur dan menganalisis menggunakan aplikasi Rasch Model. Hasil analisis menemukan nilai reliabilitas 
butir yang tinggi dengan nilai Alpha Cronbach skala kecenderungan menjadi korban bullying .870 dan .822 untuk skala kecenderungan menjadi pelaku bullying. Berikut ini sebaran butir skala kecenderungan menjadi pelaku dan korban.

Tabel 4.

Blue Print Uji Coba Skala Bullying (untuk Penelitian)

\begin{tabular}{lllll}
\hline No & Aspek & Favorable & Jumlah \\
\hline 1 & $\begin{array}{l}\text { Bullying fisik } \\
\text { dilakukan pelaku }\end{array}$ & yang & $2,4,6$ & 3 \\
2 & $\begin{array}{l}\text { Bullying fisik } \\
\text { dialami korban }\end{array}$ & yang & 1,7 & 2 \\
3 & $\begin{array}{l}\text { Bullying verbal } \\
\text { dilakukan pelaku }\end{array}$ & 8 & 1 \\
4 & $\begin{array}{l}\text { Bullying verbal yang } \\
\text { dialami korban } \\
\text { Bullying mental yang } \\
\text { dilakukan pelaku }\end{array}$ & 9,5 & 2 \\
5 & $\begin{array}{l}\text { Bullying mental yang } \\
\text { dialami korban }\end{array}$ & $10,11,12$ & 1 \\
\hline 6 & & Total & $\mathbf{1 2}$ \\
\hline
\end{tabular}

\section{Teknik Analisis}

Untuk menguji hipotesis, digunakan uji regresi linier berganda tiga prediktor. Uji regresi linier berganda dilakukan dua kali. Uji regresi linier berganda pertama dilakukan untuk menguji hubungan antara kelekatan ibu, kelekatan ayah, dan kelekatan teman sebaya dengan kecenderungan anak menjadi pelaku bullying. Uji regresi linier berganda berikutnya dilakukan untuk menguji hubungan antara kelekatan ibu, kelekatan ayah, dan kelekatan teman sebaya dengan kecenderungan anak menjadi korban bullying. Selanjutnya juga dilakukan analisis korelasi parsial untuk melihat arah hubungan dan signifikansi hubungan masing-masing variabel x terhadap variabel y.

\section{ANALISIS DAN HASIL}

Pada penelitian ini, uji hipotesis dibuktikan dengan uji regresi linier berganda. Hasil uji ini menunjukkan bahwa terdapat hubungan negatif yang sangat signifikan antara kelekatan pada ibu, ayah, dan teman sebaya dengan kecenderungan anak menjadi pelaku bullying $(r=-.329 ; p=.001)$. Hal ini menunjukkan bahwa secara bersamaan kelekatan pada ibu, ayah, dan teman sebaya dapat menurunkan kecenderungan anak menjadi pelaku bullying; artinya hipotesis pertama diterima. 
Selanjutnnya, dari uji regresi linier berganda, ditemukan hubungan negatif yang sangat signifikan antara kelekatan pada ibu, ayah, dan teman sebaya dengan kecenderungan anak menjadi korban bullying $(r=-.268, F=6.333, p=.001)$. Hal ini menunjukkan bahwa secara bersamaan kelekatan pada ibu, ayah, dan teman sebaya dapat menurunkan kecenderungan anak menjadi korban bullying; artinya hipotesis kedua juga diterima.

Sumbangan efektif kelekatan pada ibu, ayah, dan teman sebaya terhadap kecenderungan anak menjadi pelaku bullying adalah $9.7 \%$ (Adjusted $R^{2}=.097$ ) sisanya $90.3 \%$ ditentukan oleh faktor lain. Sedangkan, sumbangan efektif kelekatan pada ibu, ayah dan teman sebaya terhadap kecenderungan anak menjadi korban bullying adalah 6\% (Adjusted $R^{2}=.060$ ), sisanya 94\% ditentukan oleh faktor lain.

Setelah melakukan uji regresi linier berganda, selanjutnya dilakukan uji korelasi parsial guna menganalisis hubungan masing-masing variabel dan untuk melihat arah hubungan. Hasil uji korelasi parsial menemukan bahwa terdapat hubungan negatif yang signifikan antara kelekatan dengan ibu dan ayah dengan kecenderungan anak menjadi pelaku bullying $(B=-.026$, Beta $=-.167$, $p=.032$ untuk kelekatan dengan ibu; $B=-.018$, Beta $=-1.991, p=.048$ untuk kelekatan dengan ayah). Selanjutnya, tidak ada hubungan yang signifikan antara kelekatan dengan teman sebaya dengan kecenderungan anak menjadi pelaku bullying $(B=-.014$, Beta $=-.092, p=.169)$. Kemudian uji korelasi parsial dilakukan untuk melihat hubungan antara kelekatan dengan ibu, ayah, dan teman sebaya dengan kecenderungan anak menjadi korban bullying. Hasilnya, hanya kelekatan dengan ayah yang memiliki hubungan signifikan dengan kecenderungan anak menjadi korban bullying $(B=$ -.028 , Beta $=-.153, p=.044)$. Kelekatan dengan ibu dan teman sebaya tidak memiliki hubungan yang signifikan dengan kecenderungan anak menjadi korban bullying $(B=-.026$, Beta $=-.114, p=$ .150 untuk kelekatan dengan ibu; $B=-.014$, Beta $=-.060, p=.377$ untuk kelekatan dengan teman sebaya).

Selanjutnya juga dilakukan uji perbedaan antara kecenderungan anak laki-laki dan perempuan untuk menjadi pelaku dan korban bullying. Hasil analisis menemukan bahwa terdapat perbedaan yang signifikan pada kecenderungan anak menjadi pelaku bullying antara laki-laki dan perempuan ( $p=.013$ ), di mana laki-laki lebih berkecenderungan menjadi pelaku bullying dibandingkan perempuan (laki-laki $M=8.19$; perempuan $M=7.69$ ). Lebih lanjut, analisis uji beda mengenai kecenderungan anak menjadi korban bullying berdasarkan jenis kelamin menunjukkan bahwa tidak ada perbedaan antara laki-laki dan perempuan dalam hal kecenderungannya menjadi korban bullying $(p=.270)$. 
Berikutnya dilakukan analisis uji perbedaan kecenderungan anak menjadi pelaku bullying berdasarkan tingkatan pendidikan. Berdasarkan hasil analisis perbedaan kecenderungan anak menjadi pelaku bullying berdasarkan tingkatan pendidikan diketahui bahwa tidak ada perbedaan yang signifikan kecenderungan anak menjadi pelaku bullying antara anak SD dan SMP $(p=.289)$. Namun analisis uji perbedaan kecenderungan anak menjadi korban bullying berdasarkan tingkat pendidikan menunjukkan adanya perbedaan yang signifikan $(p=.023)$, di mana anak SD lebih cenderung untuk menjadi korban bullying dibandingkan anak SMP (SD $M=13.16$; $\operatorname{SMP} M=$ 12.68).

\section{DISKUSI}

Hasil uji regresi linier berganda pada penelitian ini menemukan bahwa terdapat hubungan negatif yang sangat signifikan antara kelekatan pada ibu, ayah, dan teman sebaya dengan kecenderungan anak menjadi pelaku dan korban bullying. Artinya, kelekatan pada ibu, ayah, dan teman sebaya mampu memprediksi anak menjadi pelaku dan korban bullying. Kelekatan yang aman dengan ibu, ayah, dan teman sebaya mampu menurunkan kecenderungan anak menjadi pelaku dan korban bullying, begitu pula sebaliknya.

Orangtua yang berperan dalam rentang kehidupan anaknya dapat memengaruhi kematangan emosional anak dalam kehidupannya. Orangtua yang mampu menciptakan kelekatan yang baik, memberikan kepercayaan (trust) dan memiliki kemampuan komunikasi (communication) yang baik dengan anaknya akan menjadikan anaknya seseorang yang mampu dalam mengelola segala aspek dalam kehidupannya. Sebaliknya, apabila orangtua tidak mampu menjadi figur yang baik bagi anak, selalu mengucilkan (alienation), dan tidak dapat menciptakan kelekatan yang aman bagi anak, akan berdampak terhadap perkembangan anak; anak dapat menjadi seorang yang kurang baik dalam kehidupan sosialnya, seperti pelaku bullying di sekolahnya atau lingkungan rumah (Wahyuni \& Asra, 2014).

Hasil penelitian ini juga sejalan dengan hasil penelitian yang ditemukan oleh Malekpour (2007), yaitu interaksi orangtua dan anak pada awal kehidupan anak berpengaruh terhadap kematangan otak anak. Anak yang memperoleh kelekatan yang aman (secure attachment) memiliki pertumbuhan dan kematangan otak yang lebih baik, sedangkan anak yang mengalami kelekatan yang tidak aman (insecure attachment) cenderung mengalami psikopatologi. Kualitas kelekatan seorang anak sangat ditentukan oleh bagaimana seorang ibu memperlakukannya. Sikap ibu yang 
kurang sensitif dan kurang responsif berkaitan dengan hubungan anak dan ibu yang tidak aman diasosiasikan dengan gangguan kelekatan (Smith, 2004).

Selanjutnya, hasil analisis korelasi parsial untuk masing-masing variabel kelekatan menunjukkan bahwa kualitas kelekatan dengan ibu dan ayah berhubungan secara signifikan dengan kecenderungan anak menjadi pelaku bullying. Namun, tidak ditemukan hubungan yang signifikan antara kelekatan dengan teman sebaya dengan kecenderungan anak menjadi pelaku bullying. Sementara itu, terkait dengan kecenderungan anak menjadi korban bullying, hanya kelekatan dengan ayah yang memiliki hubungan negatif yang signifikan, sementara kelekatan anak dengan ibu dan teman sebaya tidak memiliki hubungan yang signifikan dengan kecenderungan anak menjadi korban bullying.

Koiv (2012) menemukan bahwa pelaku bullying memiliki pola kelekatan yang tidak aman (insecure attachment) dibandingkan anak atau remaja yang tidak terlibat perilaku bullying. Nikiforou, Georgiou, dan Stavrinides (2013) juga menemukan bahwa kelekatan yang tidak berkualitas dengan orangtua memengaruhi kecenderungan anak menjadi pelaku dan korban bullying. Khususnya kelekatan pada ibu, yang ditemukan oleh Wahyuni dan Asra (2014), bahwa anak yang memiliki kualitas kelekatan yang rendah dengan ibunya yang bekerja memiliki kecenderungan anak menjadi pelaku dan korban bullying dibandingkan dengan anak yang memiliki kualitas kelekatan yang tinggi.

Dapat disimpulkan bahwa kelekatan yang aman diciptakan oleh ibu dan ayah terhadap anak dengan memberikan kepercayaan dan selalu berkomunikasi dengan anak secara baik, akan berdampak baik bagi perkembangan anak dalam kehidupannya, anak mampu terhindar dari menjadi pelaku bullying, karena anak dapat secara terbuka melakukan hal apapun.

Dalam mengasuh, ayah mengajarkan ketegasan dan kepemimpinan sehingga anak mampu menyatakan sikapnya terhadap sesuatu dengan tegas. Sejalan dengan penelitian Day dan Lamb (dalam Santrock, 2007a) yang menemukan bahwa terjadi perubahan besar terhadap peran ayah dirumah, yaitu ayah tidak hanya menjadi pencari nafkah, namun juga mengasuh anak, terutama terhadap penanaman nilai-nilai moral dan perilaku sosial. Keterlibatan ayah dalam proses perkembangan akan menimbulkan kelekatan antara ayah dan anak, dan ini yang akan mengantisipasi anak dari perilaku-perilaku yang tidak baik ketika berinteraksi dengan teman di sekolah (Santrock, 2007a).

Ahmed dan Braithwaite (2004) mengungkapkan bahwa hubungan yang harmonis antara anak dan orangtua akan membantu anak dalam menjalin hubungan harmonis dengan teman-temannya di sekolah atau di lingkungan lainnya. Amato dan Gilberth (dalam Papalia, Olds \& Feldman, 2010) 
menyatakan bahwa walaupun ayah sudah tidak tinggal serumah dengan anak, namun tetap dapat dekat dengan anaknya dan memiliki pola asuh otoritatif cenderung lebih baik di sekolah, sebaliknya anak yang tidak harmonis dengan ayahnya cenderung memiliki masalah perilaku eksternal (perilaku agresif dan perilaku bermasalah lainnya).

Disimpulkan bahwa ayah juga terlibat dalam pengasuhan, ayah sebagai figur utama di rumah yang mampu memberikan contoh kepada anak dalam kepemimpinan, prinsip, ketegasan, serta memberikan kepercayaan dan komunikasi dengan anak dan keluarga yang baik. Sehingga dapat membentuk anak yang bersikap tegas dan baik dalam kehidupan sosialnya, karena anak mengimitasi sosok yang dianggapnya sebagai orang yang hebat dan patut diteladaninya.

Hasil penelitian menunjukkan bahwa pentingnya kualitas kelekatan antara anak dan orangtua dalam membangun interaksi sosial yang aman dengan teman sebaya di sekolah. Pemahaman yang mendalam tentang faktor yang memengaruhi perilaku bullying akan memudahkan orangtua dalam menangani terjadinya perilaku bullying. Berdiskusi secara terbuka dengan anak tentang peran mereka dalam membangun interaksi sosial yang aman, berperilaku baik dan menjalin kepercayaan terhadap orang lain sebagai komponen dalam pencegahan perilaku bullying (Koiv, 2012).

Pada penelitian ini, kualitas kelekatan antara anak dengan teman sebaya tidak memiliki hubungan yang signifikan dengan kecenderungan anak menjadi pelaku dan korban bullying. Hasil penelitian ini berbeda dengan hasil penelitian yang ditemukan oleh Nikiforou dkk. (2013) yang menemukan bahwa ada hubungan antara kualitas kelekatan dengan teman sebaya dengan kecenderungan anak menjadi pelaku dan korban bullying. Hal ini mungkin karena cenderung lebih dekat dengan orangtua daripada teman sebaya sehingga bentuk kedekatan anak dengan teman sebaya tidak berpengaruh terhadap perilaku anak. Tidak adanya hubungan antara kelekatan dengan teman sebaya dengan kecenderungan anak menjadi pelaku dan korban bullying karena pada usia SD dan SMP anak masih banyak di bawah pengawasan orangtua secara langsung sehingga pengaruh teman sebaya tidak begitu kuat di banding orangtua.

Armsden, McCauley, Greenberg, Burke, dan Mitchell (1990) menemukan bahwa ada perbedaan pengaruh kelekatan antara anak dengan orangtua dan anak dengan teman sebaya terhadap kemampuan anak untuk tidak melakukan perilaku mal adaptif, cemas dan melakukan usaha bunuh diri. Kelekatan yang tidak aman antara anak dengan orangtua berhubungan dengan perilaku maladaptif, kecemasan dan keinginan untuk bunuh diri, namun tidak demikian halnya dengan kelekatan dengan teman sebaya. Kelekatan dengan teman sebaya tidak berhubungan dengan perilaku maladapatif, kecemasan, dan keinginan bunuh diri pada anak. 
Selanjutnya pada penelitian ini ditemukan bahwa sumbangan efektif kelekatan pada ibu, ayah, dan teman sebaya dengan kecenderungan anak menjadi pelaku bullying sebesar $9.7 \%$ yang artinya kelekatan pada ibu, ayah, dan teman sebaya memengaruhi anak menjadi pelaku bullying sebesar 9.7\% dan sisanya $90.3 \%$ dipengaruhi oleh faktor lain yang menjadikan anak sebagai pelaku bullying. Faktor lain itu diantaranya faktor iklim sekolah yang mana iklim sekolah yang positif menurunkan perilaku bullying (Petrie, 2014), pola asuh orangtua dan kemampuan berempati (Wahyuni \& Adiyanti, 2011).

Sumbangan efektif pada kelekatan pada ibu, ayah, dan teman sebaya dengan kecenderungan anak menjadi korban bullying sebesar 6\% yang artinya kelekatan ibu, ayah, dan teman sebaya memengaruhi anak menjadi korban bullying sebesar 6\% dan sisanya 94\% dipengaruhi oleh faktor lain, antara lain komptensi sosial (Sklar, 2011).

Penelitian ini juga menemukan bahwa anak laki-laki lebih tinggi kecenderungan menjadi pelaku bullying dibandingkan anak perempuan. Hasil penelitian ini konsisten dengan hasil penelitian sebelumnya yang menemukan bahwa laki-laki lebih tinggi kecenderungan menjadi pelaku bullying dibandingkan perempuan (Khezri dkk., 2013; Wahyuni \& Asra, 2014).

Analisis uji perbedaan berdasarkan tingkat pendidikan ditemukan bahwa anak SD dan SMP sama-sama memiliki risiko untuk menjadi pelaku bullying. Sedangkan kecenderungan menjadi korban bullying lebih tinggi pada anak SD dibandingkan anak SMP. Hal ini dikarenakan siswa SD dalam pembelaan dirinya lebih lemah dari siswa SMP sehingga mereka lebih mudah menjadi korban bullying (Wahyuni \& Asra, 2014). Dalam analisis perbedaan tersebut, terdapat beberapa perbedaan antara siswa SD dan SMP, karena siswa SD dengan SMP juga memiliki perbedaan dalam proses kognitif dan berpikir, untuk usia SD yang rata-rata dalam usia 9 dan 10 tahun, anak yang cenderung menjadi korban bullying dalam proses pembelaan diri serta berpikir formal dalam pemecahan masalah masih terbatas.

Sejalan dengan Piaget (dalam Santrock, 2007b), yang menyatakan dalam proses kognitif di tahap operasi berpikir konkrit (7-11) tahun, tahap ini dicirikan dengan sistem pemikiran yang didasarkan pada aturan-aturan yang logis. Gunarsa (dalam Papalia dkk., 2010) menyatakan kemampuan anak untuk melakukan operasimental dan kognitif, memungkinkan anak mengadakan hubungan yang luas dengan dunianya. Operasi mental merupakan peristiwa-peristiwa yang terjadi di dalam diri anak, yang memungkinkan anak mengetahui suatu perbuatan tanpa melihat bahwa perbuatan tersebut ditunjukkan. Serta pada tahap ini kemampuan berpikir anak masih terbatas pada hal-hal yang ada hubungannya dengan suatu yang konkrit. Benda-benda atau kejadian yang tidak 
ada hubungannya secara jelas dan konkrit dengan realitas, masih sulit dipikirkan anak (Gunarsa, dalam Papalia dkk., 2010).

Berdasarkan penjelasan di atas, dapat disimpulkan bahwa kelekatan anak dengan orangtua juga sangat penting. Interaksi yang baik antara anak dengan orangtua membantu anak dalam menjalin interkasi sosial yang baik dengan orang lain dan mencegah anak dari perilaku yang tidak diinginkan. Namun demikian, kelekatan anak dengan teman sebaya tidak berkaitan dengan kecenderungan anak menjadi pelaku dan korban bullying, artinya lekat atau tidak anak dengan teman sebaya ternyata tidak berpengaruh terhadap kecenderungan anak menjadi pelaku dan korban bullying.

Keterbatasan terkait dengan penelitian ini ialah peneliti belum melihat bentuk-bentuk kelekatan yang berhubungan dengan kecenderungan anak menjadi pelaku dan korban bullying, sehingga belum diketahui bentuk kelekatan yang tepat yang dapat digunakan orangtua guna mencegah anaknya menjadi pelaku atau korban bullying.

\section{SIMPULAN DAN SARAN}

\section{Simpulan}

Berdasarkan hasil analisis dan pembahasan dalam penelitian ini dapat ditarik kesimpulan bahwa terdapat hubungan negatif yang sangat signifikan antara kelekatan pada ibu dan ayah dengan kecenderungan anak menjadi pelaku bullying. Hasil penelitian ini juga menemukan bahwa tidak terdapat hubungan yang signifikan antara kelekatan dengan teman sebaya dengan kecenderungan anak menjadi pelaku dan korban bullying; artinya lekat atau tidaknya anak dengan teman sebaya sama-sama memiliki risiko untuk terlibat dalam perilaku bullying, baik itu sebagai pelaku maupun sebagai korban. Pada kecenderungan anak menjadi korban bullying, hanya kelekatan dengan ayah yang memiliki hubungan negatif yang signifikan dengan kecenderungan anak menjadi korban bullying.

\section{Saran Teoretis}

Bagi peneliti selanjutnya yang berminat untuk melakukan penelitian tentang bullying, disarankan untuk meneliti bentuk-bentuk kelekatan yang dapat mencegah anak untuk menjadi pelaku maupun korban bullying. Selain itu, peneliti selanjutnya juga dapat meneliti berbagai faktor 
lain yang dapat memengaruhi seseorang untuk menjadi pelaku dan korban bullying, misalnya iklim sekolah, kelekatan anak dengan guru, dan kompetensi sosial anak.

\section{Saran Praktis}

Berdasarkan hasil penelitian yang menemukan bahwa ada hubungan negatif antara kelekatan dengan ibu dan ayah dengan kecenderungan anak menjadi pelaku bullying, maka disarankan kepada orangtua untuk menciptakan kelekatan yang aman dengan anak agar anak dapat terhindar dari risiko menjadi pelaku bullying. Ayah dan ibu hendaknya menjadikan hubungan yang saling percaya dengan anak, menjalin komunikasi yang efektif dan memberikan dukungan kepada anak, dan menghindari dari pengasuhan yang mengabaikan dan mengucilkan anak. Khususnya pada ayah, peran ayah dalam memberikan kelekatan yang aman pada anak sangat penting karena selain dapat mencegah anak dalam melakukan bullying, kelekatan yang aman dengan ayah juga dapat menghindarkan anak dari menjadi korban bullying.

\section{REFERENSI}

Ahmed, E., \& Braithwaite, V. (2004). Bullying and victimization: Cause for concern for both families and schools. Social Psychology of Education, 7, 5-54.

Andreou, E. (2001). Bully/victim problems and their association with coping behavior in conflictual peer interactions among school-age children. Educational Psychology, 21(1), 59-66.

Appleyard, K., \& Berlin, L. J. (2007). Supporting healthy relationship between young children and the parents. Center For Child and Policy Duke University. Ditemu kembali dari https://childandfamilypolicy.duke.edu/pdfs/pubpres/SupportingHealthyRelationships.pdf

Armsden, G., \& Greenberg, M. T. (2009). Inventory of Parent and Peer Attachment (IPPA). College of Health and Human Development. Ditemu kembali dari http://www.prevention.psu.edu/media/prc/files/IPPAManualDecember2013.pdf

Armsden, G. C., McCauley, E., Greenberg, M. T., Burke, P. M., \& Mitchell, J. R. (1990). Parent and peer attachment in early adolescent depression. Journal of Abnormal Child Psychology, $18(6), 683-697$.

Azzura, S. N. (2015). Miris anak ini alami trauma setelah dianiaya teman sekolahnya. Merdeka. Ditemu kembali dari http://www.merdeka.com/peristiwa/miris-anak-ini-alami-trauma-setelahdianiaya-teman-sekolahnya.html 
Bowlby, J. (1958). The nature of the child's tie to his mother. International Journal of PsychoAnalysis, 39, 350-373.

Eisenberg, N. (2006a). Empathy and fairness. Hoboken, NJ: John Wiley \& Sons.

Eisenberg, N. (2006b). Empathy-related responding and prosocial behaviour. Hoboken, NJ: John Wiley \& Sons.

Glew, G. M., Fan, M. -Y., Katon, W., Rivara, F. P., \& Kernic, M. A. (2005). Bullying, psychosocial adjustment, and academic performance in elementary school. Arch Pediatr Adolesc Med, 159, 1026-1031.

Hazan, C., \& Shaver, P. R. (1994). Attachment as an organization framework for research for close relationship. Psychological Inquiry, 5(1), 1-22.

Khezri, H., Ghavam, S. E., Mofidi, F., \& Delavar, A. (2013). Bullying and victimization: Prevalence and gender differences in a sample of Iranian Middle School Students. Journal of Educational and Management Studies. 3(3), 224-229.

Koiv, K. (2012). Attachment styles among bullies, victims and uninvolved adolescents. Psychology Research, 2(3), 160-165.

Konishi, C., \& Hymel, S. (2009). Bullying and stress in early adolescence: The role of coping and social support. Journal of Early Adolescence, 29(3), 333-356.

Kowalski, R. M., \& Limber, S. P. (2013). Psychological, physical, and academic correlates of cyber bullying and traditional bullying. Journal of Adolescent Health, 53, 13-20.

Leidy, M. S., Guerra, N. G., \& Toro, R. I. (2010). Positive parenting, family cohesion, and child social competence among immigrant Latino families. Journal of Family Psychology, 24(3), $252-260$.

Lines, D. (2008). The bullies: Understanding bullies and bullying. London: Jessica Kingsley.

Malekpour, M. (2007). Effect of attachment on nearly and later development. The British Journal of Developmental Disabilities, 53(105), 81-95.

Malti, T., Perren, S., \& Buchmann, M. (2010). Children's peer victimization, empathy, and emotional symptoms. Child Psychiatry and Human Development, 41(1), 98-113.

Nansel, T. R., Overpeck, M., Pilla, R. S., Ruan, W. J., Simons-Morton, B., \& Scheidt, P. (2001). Bullying behaviors among U.S. youth: Prevalence and association with psychosocial adjustment. Journal of the American Medical Association, 285(16), 2094-2100. 
Nikiforou, M., Georgiou, S. N., \& Stavrinides, P. (2013). Attachment to parents and peers as a parameter of bullying and victimization. Hindawi Publishing Corporation Journal of Criminology, 2013, 1-9.

Oates, J. (Ed.) (2007). Attachment relationships: quality of care for young children. Early childhood in focus. Walton Hall, UK: The Open University.

O’Connor, T. G., \& Scott, S. B. C. (2007). Parenting and outcomes for children. London: Joseph Rowntree Foundation.

Olweus, D. (1997). Bully/victim problems in school: fact and intervention. European Journal of Psychology of Education, 12(4), 495-510.

Papalia, D. E., Olds, S. W., \& Feldman, R. D. (2010). Human development: Psikologi perkembangan. (9th ed.) (A. K. Anwar, Trans.). Jakarta: Kencana Prenada Media Group.

Pei, M. (2011). The relation between parent-child attachment, childrearing behaviors, and aggression in childhood and adolescence (Tesis tidak dipublikasikan). Brandeis University, USA.

Petrie, K. (2014). The relation between school climate and student bullying. THEACH Journal of Christian Education, 8(1), 26-35.

Rasyid, M., \& Suminar, D. R. (2012). Hubungan antara peer attachment dengan regulasi emosi remaja yang menjadi siswa di boarding school SMA Negeri 10 Samarinda. Jurnal Psikologi Pendidikan dan Perkembangan, 1(3), 1-7.

Santrock, J. W. (2007a). Perkembangan masa hidup: Jilid 2. Jakarta: Erlangga.

Santrock, J. W. (2007b). Child development (11th ed.). New York, NY: McGraw-Hill.

Schneider, B. H., Atkinson, L., \& Tardif, C. (2001). Child-parent attachment and children's peer relations: A quantitative review. Developmental Psychology, 37(1), 86-100.

Sejiwa. (2008). Bullying: Mengatasi kekerasan di sekolah dan lingkungan sekitar anak. Jakarta: Grasindo.

Sklar, N. (2011). Social competence as a moderator of the aggression-victimization link in elementary school children (Tesis tidak dipublikasikan). University of Victoria, Canada.

Smith, P. R. (2004). Caring for paid caregivers: Linking quality childcare with improved working conditions. University of Cincinnati Law Review, 73,399-404.

Sudiaman, M. (2014). Inilah kronologi kasus bully anak SD di Bukittinggi. News Republika.co.id. Ditemu kembali dari http://www.republika.co.id/berita/nasional/daerah/14/10/12/ndbsmginilah-kronologi-kasus-bully-anak-sd-di-bukittinggi 
Sumintono, B., \& Widhiarso, W. (2014). Aplikasi model rasch untuk penelitian ilmu-ilmu sosial. Bandung: Trim Komunika.

Totura, C. M. W., MacKinnon-Lewis, C., Gesten, E. L., Gadd, R., Divine, K. P., Dunham, S., \& Kamboukos, D. (2009). Bullying and victimization among boys and girls in middle school: The influence of perceived family and school contexts. Journal of Early Adolescence, 29(4), 571-609.

Uba, I., Yaacob, S. N., \& Juhari, R. (2009). The relationship between peer relations and depression among adolescents in Selangor, Malaysia. European Journal of Social Sciences, 11(1), 149159.

Uba, I., Yaacob, S. N., Juhari, R., \& Talib, M. A. (2010). Effect of self-esteem on the relationship between depression and bullying among teenagers in Malaysia. Asian Social Science, 6(12), $77-85$.

Veríssimo, M., Santos, A. J., Vaughn, B. E., Torres, N., Monteiro, L., \& Santos, O. (2011). Quality of attachment to father and mother and number of reciprocal friends. Early Child Development and Care, 181(1), 27-38.

Wahyuni, S., \& Adiyanti, M. G. (2011). Correlation between perception toward parent's authoritarian parenting and ability to empathize with tendency of bullying behavior on teenagers. Jurnal Psikologi, 7(2), 106-118.

Wahyuni, S., \& Asra, Y. K. (2014). Kecenderungan anak menjadi pelaku dan korban bullying ditinjau dari kualitas kelekatan dengan ibu yang bekerja. Marwah, 13(1), 1-20.

Wahyuni, S., \& Nazifah, N. (2012). Studi cross-sectional perilaku bullying pada siswa SD, SMP, dan SMU di kota Pekanbaru Riau, Prosiding: Kumpulan Artikel Temu Ilmiah Psikologi Sosial Indonesia, Riau, 2-3 November, 2012. Riau: Ikatan Psikologis Sosial dan Fakultas Psikologi UIN Suska Riau.

Walden, L. M., \& Beran, T. N. (2010). Attachment quality and bullying behavior in school-aged youth. Canadian Journal of School Psychology, 25(1), 5-18.

Wolke, D., Woods, S., Stanford, K., \& Schulz, H. (2001). Bullying and victimization of primary school children in England and Germany: Prevalence and school factors. British Journal of Psychology, 92, 673-696. 